\title{
Pengaruh Upah Minimum, Produk Domestik Bruto Sektor Industri dan Inflasi Terhadap Kepesertaan BPJS Ketenagakerjaan
}

\author{
Gatot Sasongko ${ }^{1 *}$, Yosep Agung Supriyanto ${ }^{2}$, Yustinus Wahyudi ${ }^{3}$
}

1,2,3Fakultas Ekonomika dan Bisnis Universitas Kristen Satya Wacana

\author{
A R T I C L E I N F O \\ Article history: \\ Received 19 May 2019 \\ Received in revised form \\ 16 June 2019 \\ Accepted 15 July 2019 \\ Available online 26 August \\ 2019 \\ Kata Kunci: \\ Kepesertaan BPJS \\ Ketenagakerjaan, Upah \\ Minimum, PDB Sektor \\ Industri, Inflasi. \\ Keywords: \\ Partisipation of BPJS \\ Ketenagakerjaan, Minimum \\ Wages, Industrial Sector of \\ GDP, Inflation.
}

\begin{abstract}
A B S T R A K
Tujuan dari penelitian ini adalah untuk mengetahui dan menganalisis pengaruh dari upah minimum, PDB sektor industri dan inflasi terhadap kepesertaan BPJS Ketenagakerjaan penerima upah tahun 2000-2017. Penelitian ini menggunakan data sekunder yang bersumber dari Laporan Tahunan PT. Jamsostek (Persero)/BPJS Ketenagakerjaan tahun 2000-2017 dan Badan Pusat Statistik (BPS) tahun 2018 dan 2019. Analisis yang digunakan dalam penelitian ini adalah analisis time series, yaitu data 18 tahun (2000-2017). Upah minimum dan PDB sektor industri memiliki pengaruh positif secara signifikan terhadap kepesertaan BPJS Ketenagakerjaan penerima upah tahun 2000-2017. Sedangkan variabel inflasi tidak berpengaruh terhadap kepesertaan BPJS Ketenagakerjaan penerima upah tahun 2000-2017.
\end{abstract}

The purpose of this study was to find out and analyze the effect of minimum wages, industrial sector of GDP and inflation on the wage earning participants of BPJS Ketenagakerjaan from 20002017. This study used secondary data sourced from the Annual Report of PT. Jamsostek (Persero)/BPJS Ketenagakerjaan from 2000-2017 and Badan Pusat Statistik (BPS) in 2018 and 2019. The analysis used in this study was a time series analysis, with 18 observations. The minimum wage and industrial sector of GDP have a significant positive influence on the wage earning participants of BPJS Ketenagakerjaan from 2000-2017. While, the inflation variable didn't have effect on the wage earning participants of BPJS Ketenagakerjaan from 2000-2017.

\footnotetext{
* Corresponding author.

E-mail addresses: GatotSasongko13@gmail.com (Gatot Sasongko)
} 


\section{Pendahuluan}

Dalam rangka melaksanakan tujuan negara yang telah tercantum dalam pembukaan UndangUndang Dasar 1945, pemerintah dengan gencar melaksanakan pembangunan disegala bidang untuk meningkatkan kesejahteraan masyarakat. Sumber daya manusia (SDM), dalam hal ini tenaga kerja merupakan salah satu bagian terpenting dari proses produksi juga tak luput dari perhatian pemerintah. Perusahaan, dalam hal ini adalah sebagai pemberi kerja tentu berkewajiban untuk memberikan rasa aman pada pekerjanya agar produktivitas pekerjanya juga akan meningkat. Salah satu hal yang dapat meningkatkan produktivitas dari pekerja adalah ada tidaknya jaminan sosial yang didapatkan ketika melaksanakan proses produksi. Jaminan sosial juga merupakan bentuk perhatian dari perusahaan untuk para pekerjanya, khususnya jaminan sosial ketenagakerjaan.

Terjaminnya dasar kehidupan layak bagi masyarakat terlihat pada adanya perlindungan sosial. Berdasarkan Undang-Undang Nomor 24 tahun 2011 tentang Badan Penyelenggara Jaminan Sosial dinyatakan bahwa sistem jaminan sosial nasional yaitu program yang diselenggarakan oleh negara yang bertujuan memberikan kepastian perlindungan dan kesejahteraan sosial bagi seluruh rakyat; untuk mewujudkan tujuan dari sistem jaminan sosial nasional tersebut, diperlukan badan penyelenggara yang berbentuk badan hukum dengan berdasarkan prinsip kegotongroyongan, keterbukaan, dana amanat, nirlaba, akuntabilitas, kehati-hatian, profitabilitas, kepesertaan bersifat wajib, dan hasil pengelolaan dana jaminan sosial seluruhnya untuk pengembangan program dan untuk kepentingan peserta.

BPJS Ketenagakerjaan pada awalnya disebut PT Jaminan Sosial Tenaga Kerja atau disingkat PT Jamsostek (Persero) dan mulai resmi disebut BPJS Ketenagakerjaan pada tahun 2014. Sebagai salah satu badan penyelenggara jaminan sosial seperti yang diamanatkan dalam Undang-Undang Nomor 24 tahun 2011 tentang Badan Penyelenggara Jaminan Sosial, BPJS Ketenagakerjaan dibentuk untuk menyelenggarakan 4 (empat) program jaminan sosial, yaitu jaminan kecelakaan kerja, jaminan hari tua, jaminan pensiun dan jaminan kematian.

Kepesertaan BPJS Ketenagakerjaan bersifat wajib bagi pekerja, dengan maksud agar terlindungi dari berbagai resiko sosial ekonomi yang bisa sewaktu-waktu menimpa. Namun demikian, penerapan dalam proses kepesertaan tetap disesuaikan dengan kemampuan ekonomi masyarakat dan pemerintah serta kelayakan dalam penyelenggaraan program. Setiap individu dalam masyarakat, dalam hal ini juga termasuk orang asing yang bekerja paling sedikit 6 (enam) bulan di Indonesia dan yang telah membayar iuran sudah dapat disebut peserta BPJS Ketenagakerjaan. Peserta BPJS Ketenagakerjaan dibedakan menjadi 2 (dua), yaitu Peserta Penerima Upah (PU) dan Peserta Bukan Penerima Upah (BPU). Peserta yang termasuk dalam kategori Penerima Upah (PU) adalah mereka yang bekerja dengan memperoleh gaji, upah, atau imbalan dalam bentuk lain dari pemberi kerja (BPJS Ketenagakerjaan 2019). Kondisi kepesertaan BPJS Ketenagakerjaan terhadap jumlah pekerja penerima upah di Indonesia selama 18 tahun terakhir dapat dilihat dalam tabel berikut.

Tabel 1. Pekerja Penerima Upah dan Peserta Aktif BPJS Ketenagakerjaan Penerima Upah tahun 20002017

\begin{tabular}{cccc}
\hline Tahun & $\begin{array}{c}\text { Pekerja Penerima Upah } \\
\text { (buruh/karyawan/ } \\
\text { pegawai) }\end{array}$ & $\begin{array}{c}\text { Peserta BPJS } \\
\text { Ketenagakerjaan } \\
\text { Penerima Upah }\end{array}$ & $\begin{array}{c}\text { Proporsi Peserta BPJS } \\
\text { Ketenagakerjaan Penerima Upah } \\
\text { terha-dap jumlah Pekerja Penerima } \\
\text { Upah (\%) }\end{array}$ \\
\hline 2000 & 29.498 .039 & 8.104 .333 & 27,47 \\
2001 & 26.579 .000 & 8.450 .425 & 31,79 \\
2002 & 25.049 .793 & 8.018 .710 & 32,01 \\
2003 & 24.149 .886 & 8.332 .057 & 34,50 \\
2004 & 25.459 .554 & 7.762 .219 & 30,49 \\
2005 & 26.027 .953 & 7.791 .730 & 29,94 \\
2006 & 26.821 .889 & 7.665 .985 & 28,58 \\
2007 & 28.042 .390 & 7.857 .111 & 28,02 \\
2008 & 28.183 .773 & 8.092 .360 & 28,71 \\
2009 & 29.114 .041 & 8.292 .914 & 28,48 \\
2010 & 32.521 .517 & 9.464 .157 & 29,10 \\
\hline
\end{tabular}




\begin{tabular}{lccc}
\hline 2011 & 36.912 .535 & 10.116 .935 & 27,41 \\
2012 & 40.868 .630 & 11.094 .713 & 27,15 \\
2013 & 41.123 .849 & 11.927 .458 & 29,00 \\
2014 & 42.382 .148 & 16.100 .961 & 37,99 \\
2015 & 44.434 .390 & 18.988 .996 & 42,73 \\
2016 & 45.827 .785 & 21.254 .010 & 46,38 \\
2017 & 48.047 .068 & 24.527 .863 & 51,05 \\
\hline & Sumber: BPS (2018) dan Laporan Tahunan PT Jamsostek (Persero)/BPJS Ketenagakerjaan tahun \\
\end{tabular}

Besarnya jumlah pekerja penerima upah cenderung mengalami kenaikan setiap tahun, begitu pula halnya dengan jumlah peserta aktif BPJS Ketenagakerjaan penerima upah yang dari tahun ketahun mengalami peningkatan. Kenaikan peserta aktif penerima upah terbesar terjadi di tahun 2014, yaitu sebesar 25,92\% dari tahun 2013 atau naik dari angka 11,93 juta jiwa menjadi 16,10 juta jiwa ditahun 2014. Pada tahun itu pula terjadi transformasi dari PT Jamsostek (Persero) menjadi BPJS Ketenagakerjaan. Perubahan tersebut memberikan dampak secara signifikan terhadap kenaikan jumlah peserta penerima upah BPJS Ketenagakerjaan. Meski kepesertaan BPJS Ketenagakerjaan mengalami peningkatan, namun angka tersebut masihlah rendah jika dibanding jumlah pekerja penerima upah di Indonesia. Terlihat dari tahun 2000-2016, belum ada 50\% dari pekerja penerima upah yang terdaftar sebagai peserta BPJS Ketenagakerjaan. Baru ditahun 2017 mampu mencapai angka 51,05\%. Hal tersebut membuktikan bahwa masih rendahnya kesadaran baik dari pihak perusahaan maupun pekerja dalam menanggapi jaminan sosial. Hal ini juga yang menjadikan masalah karena pada dasarnya sudah ditetapkan oleh undang-undang bahwa menjadi peserta BPJS Ketenagakerjaan adalah kewajiban bagi pekerja, namun saat melihat proporsi dari pekerja penerima upah terhadap peserta BPJS Ketenagakerjaan, faktanya tidak demikian. Tentu hal tersebut disebabkan oleh beberapa faktor sehingga mendorong perusahaan maupun tenaga kerja untuk mendaftarkan dirinya dalam program jaminan sosial yang diselenggarakan oleh BPJS Ketenagakerjaan. Beberapa faktor tersebut antara lain adalah upah minimum, Produk Domestik Bruto (PDB) sektor industri dan inflasi.

Seiring dengan berkembangnya zaman dan semakin maraknya perusahaan-perusahaan industri, tentu jaminan sosial menjadi hal penting yang wajib diperhatikan bagi pemberi kerja dan pekerja. Beberapa penelitian terdahulu telah mengungkap pengaruh upah minimum terhadap kepesertaan suatu program jaminan sosial atau asuransi jiwa. Penelitian Rohmawati et al. (2014) di Surakarta, Ariska et al. (2016) di Kabupaten Jember, Puspitasari (2017) di Kabupaten Jamber dan Hasibuan (2017) di Provinsi DKI Jakarta mengungkapkan bahwa upah minimum memiliki pengaruh positif signifikan terhadap kepesertaan jaminan sosial. Hal tersebut menunjukkan bahwa semakin tinggi upah yang diterima masyarakat akan meningkatkan kepesertaan dari suatu jaminan sosial. Melihat dari sisi internasional, penelitian Burić et al. (2017) di 6 negara Balkan Barat tahun 2005-2015 menemukan pengaruh positif antara upah minimum terhadap kepesertaan asuransi jiwa yang berlaku di negara masing-masing. Namun penelitian dari Gultom (2016) di Indonesia, Prasetyo (2016) di Kabupaten Sintang tahun 2015 dan Pangestika et al. (2017) di Kota Pekalongan mengungkapkan bahwa upah minimum tidak berpengaruh terhadap kepesertaan jaminan sosial. Saat kondisi upah mengalami kenaikan maupun penurunan, hal tersebut tidak ada pengaruhnya bagi kepesertaan jaminan sosial. Hasil penelitian yang berbeda menjadi pendorong untuk melakukan penelitian tentang pengaruh upah minimum terhadap kepesertaan BPJS Ketenagakerjaan penerima upah tahun 2000-2017.

Melihat dari sisi Produk Domestik Bruto (PDB), penelitian-penelitian sebelumnya menunjukkan perbedaan hasil. Penelitian Ward dan Zurbruegg (2002) di 37 negara yang tergabung dalam Organization for Economic Cooperation and Development (OECD) dan Asia periode 1987 - 1998, Kugler dan Ofoghi (2005) di Inggris selama periode 1966-2003, Adams et al., (2005) pada Swedia untuk periode 1830-1998, Arena (2006) di 56 negara industri dan berkembang, Njegomir dan Stojić (2010) di Yugoslavia untuk periode 2004-2008, Kjosevaki (2012) pada 14 negara Eropa Tengah dan Tenggara tahun 1998-2010, Zouhaier (2014) pada 23 negara anggota OECD tahun 1990-2011 dan Burić et al. (2017) di 6 negara Balkan Barat periode 2005-2015, menunjukkan bahwa PDB memiliki pengaruh positif signifikan terhadap kepesertaan jaminan sosial atau asuransi jiwa. Tidak hanya dikawasan internasional, Prihantoro et al. (2013) yang melakukan penelitian di Indonesia menemukan bahwa PDB Indonesia pada tahun 2006-2011 memiliki pengaruh positif terhadap kepesertaan asuransi jiwa. Hasil berbeda ditemukan oleh Gultom (2016) yang menyatakan bahwa tidak ada pengaruh signifikan antara PDB dengan kepesertaan BPJS Ketenagakerjaan pada tahun 1997-2015. Hasil penelitian yang berbeda ini menjadi pendorong untuk 
melakukan penelitian ulang tentang pengaruh PDB terhadap kepesertaan BPJS Ketenagakerjaan penerima upah tahun 2000-2017.

Penelitian mengenai pengaruh inflasi terhadap kepesertaan jaminan sosial yang dilakukan oleh Boubaker dan Sghaier (2012) dalam jangka panjang pada 14 negara maju tahun 1965-2008 dan Prihantoro et al. (2013) di Indonesia tahun 2006-2011 menyatakan bahwa terdapat pengaruh negatif signifikan antara tingkat inflasi dengan kepesertaan jaminan sosial. Saat terjadi inflasi tinggi, akan menurunkan minat atau permintaan keikutsertaan pada program jaminan sosial. Namun hasil berbeda ditemukan oleh Nesterova (2008) dari data historis 11 tahun terhadap 14 negara di Eropa Timur dan Kjosevaki (2012) pada 14 negara Eropa Tengah dan Tenggara tahun 1998-2010 yang dalam penelitiannya menyatakan bahwa inflasi tidak berpengaruh terhadap kepesertaan jaminan sosial. Hal inilah yang mendorong penelitian ini dilakukan dengan melihat pengaruh inflasi Indonesia terhadap kepesertaan BPJS Ketenagakerjaan penerima upah tahun 2000-2017.

Berdasarkan latar belakang tersebut, tujuan dari penelitian ini untuk menganalisis pengaruh upah minimum, PDB sektor industri dan inflasi terhadap kepesertaan BPJS Ketenagakerjaan penerima upah tahun 2000-2017.

Dari hasil penelitian ini diharapkan dapat memberikan manfaat bagi pemerintah, khususnya BPJS Ketenagakerjaan agar mengeluarkan kebijakan yang tepat dengan melihat faktor-faktor makro ekonomi di Indonesia, sehingga perusahaan maupun pekerja akan semakin tertarik untuk menjadi peserta BPJS Ketenagakerjaan. Bagi perusahaan, diharapkan semakin sadar akan pentingnya jaminan sosial, sehingga perusahaan akan mengikutsertkan seluruh pekerjanya pada program jaminan sosial BPJS Ketenagakerjaan.

\section{Metode}

Penelitian ini dilakukan menggunakan pedekatan secara kuantitatif, yaitu suatu penelitian yang menggambarkan hubungan kausal antara variabel-variabel melalui pengujian hipotesis, dengan menggunakan metode analisis statistik regresi berganda.

Variabel - variabel penelitian yang digunakan pada penelitian terdiri dari variabel terikat yaitu variabel kepesertaan BPJS Ketenagakerjaan penerima upah dan variabel bebas terdiri: upah minimum, PDB sektor industri dan inflasi. Pada penelitian kali ini menggunakan data sekunder yang bersumber dari Laporan Tahunan PT. Jamsostek (Persero)/BPJS Ketenagakerjaan dari tahun 2000-2017 dan Badan Pusat Statistik (BPS) tahun 2018 dan 2019.

Data yang dienelisis merupakan data time series, yaitu data 18 tahun (2000-2017). Guna mengetahui besarnya pengaruh variabel terikat terhadap variabel bebas, maka pada penelitian ini memakai model Regresi Linier Berganda (Multiple Regression) dengan tujuan untuk mengetahui bagaimana pengaruh variabel-variabel bebas terhadap variabel terikat baik secara langsung maupun tidak langsung.

Regresi linier, dimana sebuah variabel terikat (variabel Y) dihubungkan dengan dua atau lebih variabel bebas (variabel X) dapat disebut juga dengan regresi linier berganda. Secara umum, bentuk persamaan regresinya adalah sebagai berikut:

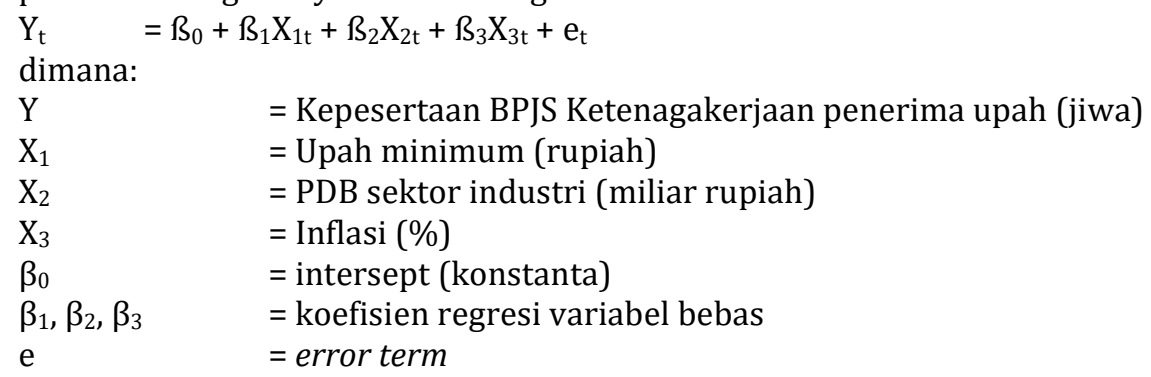

Untuk mencapai tujuan penelitian, analisis data pada penelitian dilakukan melalui model ekonometrika dengan bantuan program Eviews 9. Adapun tahap-tahap analisis meliputi uji asumsi klasik dan pengujian hipotesis.

Alat Analisis

Sebelum melakukan analisis data, dipastikan terlebih dahulu bahwa data yang akan digunakan telah lolos uji asumsi klasik, yaitu data terdistribusi normal, data terbebas dari gejala heteroskedastisitas, gejala multikolinearitas, dan gejala autokorelasi (Gujarati 2012). Setelah data sudah lolos uji asumsi klasik, kemudian dilanjutkan dengan pengujian hipotesis. 


\section{Uji Asumsi Klasik}

Uji asumsi klasik memberikan kepastian bahwa persamaan regresi yang diperoleh mempunyai ketepatan dalam estimasi, tidak bias dan konsisten. Pengujian asumsi klasik dibutuhkan untuk mengetahui apakah data berdistribusi secara normal dan hasil estimasi regresi yang dilakukan benarbenar bebas dari adanya gejala heteroskedastisitas, gejala multikolinearitas, dan gejala autokorelasi (Gujarati 2012). Berikut adalah hasil uji normalitas data:

Uji Normalitas

Tujuan dilakukannya pengujian normalitas adalah untuk melihat normal tidaknya data yang dianalisis. Model regresi yang baik semestinya mempunyai distribusi data normal atau mendekati normal. Dalam uji normalitas, dapat dilihat melalui uji Jerque-Bera (JB-test). Jika diketahui bahwa nilai probability $>\alpha(0.05)$, maka data tersebut berdistribusi normal. Namun jika nilai probability $<\alpha(0.05)$, maka data tersebut tidak berdistribusi secara normal (Gujarati 2012).

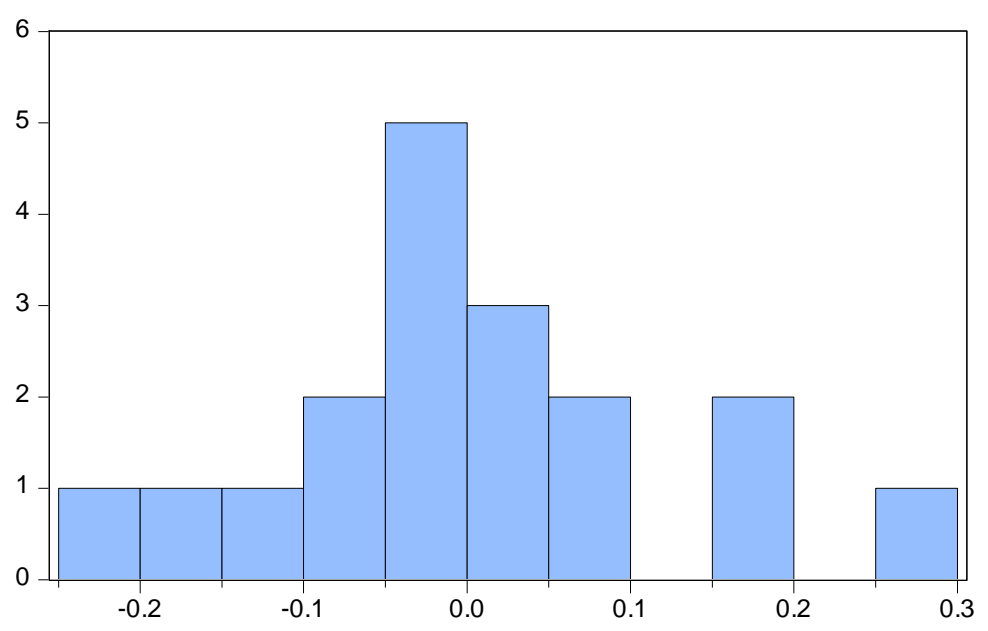

Gambar 2. Hasil Uji Normalitas

\begin{tabular}{|c|c|}
\hline \multicolumn{2}{|c|}{$\begin{array}{l}\text { Series: Residuals } \\
\text { Sample } 20002017 \\
\text { Observations } 18\end{array}$} \\
\hline Mean & $-2.47 e-15$ \\
\hline Median & -0.009717 \\
\hline Maximum & 0.257461 \\
\hline Minimum & -0.226510 \\
\hline Std. Dev. & 0.120738 \\
\hline Skewness & 0.355420 \\
\hline Kurtosis & 3.011295 \\
\hline Jarque-Bera & 0.379066 \\
\hline Probability & 0.827345 \\
\hline
\end{tabular}

Sumber : Lampiran 1

Uji normalitas melalui uji Jerque-Bera (JB-test) diketahui bahwa nilai probability $>\alpha(0,05$ atau $5 \%)$, yaitu $0.8273>0.05$, maka data berdistribusi normal (Gujarati 2012).

Uji Multikoliniearitas

Uji multikoliniearitas bertujuan untuk menguji apakah model regresi terdapat korelasi antar variabel bebas atau tidak. Seharusnya, model regresi yang baik tidak terjadi korelasi diantara variabel bebas. Menurut Gujarati (2012), jika koefisien korelasi antar variabel bebas lebih dari 0,8 maka dapat disimpulkan bahwa model mengalami masalah multikolinearitas. Sebaliknya, jika koefisien korelasi kurang dari 0,8 maka model bebas dari multikolinearitas.

Tabel 2. Hasil Uji Multikoliniearitas

\begin{tabular}{cccc}
\hline & UMP & PDBLN & INFLASI \\
\cline { 2 - 4 } UMP & 1 & -0.15185221154 & 0.11483248737 \\
PDBLN & -0.15185221154 & 1 & -0.51772522005 \\
INFLASI & 0.11483248737 & -0.51772522005 & 1 \\
\hline
\end{tabular}

Uji multikoliearitas menyatakan koefisien korelasi dari masing-masing variabel bebas adalah kurang dari 0,8 yang berarti model bebas dari multikolinearitas (Gujarati 2012)

Uji Heteroskedastisitas

Pengertian dari heteroskedastisitas adalah kondisi dimana penyebaran data yang tidak sama atau tidak samanya variansi sehingga uji siginifikansi tidak valid. Tujuan dari uji heteroskedastisitas guna mengetahui apakah dalam sebuah model regresi terjadi ketidaksamaan varian residual (kesalahan penganggu) dari satu pengamatan ke pengamatan yang lain (Gujarati 2012). Dalam menguji heteroskedastisitas ini menggunakan White test, dimana jika Prob. Chi-Square $<\alpha(0.05)$, maka terjadi 
gejala heteroskedastisitas, sebaliknya jika Prob. Chi-Square $>\alpha$ (0.05), maka tidak terjadi gejala heteroskedastisitas (homoskedastisitas).

Tabel 3. Hasil Uji Heteroskedastisitas

\begin{tabular}{lllc}
\hline Heteroskedasticity Test: White & & \\
\hline F-statistic & 3.703100 & Prob. F(9,8) & 0.0394 \\
Obs*R-squared & 14.51567 & Prob. Chi-Square(9) & 0.1051 \\
Scaled explained SS & 8.830674 & Prob. Chi-Square(9) & 0.4530 \\
\hline
\end{tabular}

Heterokedastisitas menggunakan White test menghasilkan nilai Prob. Chi-Square $>\boldsymbol{\alpha}$, yaitu 0.4530 $>0.05$, maka tidak terjadi gejala heteroskedastisitas atau data tersebut homoskedastisitas (Gujarati 2012).

Uji Autokorelasi

Autokorelasi merupakan korelasi antara anggota serangkaian observasi yang diurutkan menurut deret waktu. Pengujian yang sering dilakukan untuk mendeteksi autokorelasi adalah Breusch-Godfrey Serial Correlation LM Test dimana jika Prob. Chi-Square $<\alpha=0.05$, maka terjadi gejala autokorelasi, sebaliknya jika Prob. Chi-Square $>\alpha$ (0.05), maka tidak terjadi gejala autokorelasi (Gujarati 2012).

Tabel 4. Hasil Uji Autokorelasi

\begin{tabular}{lcll}
\hline Breusch-Godfrey Serial Correlation LM Test: & & \\
\hline F-statistic & 0.451177 & Prob. F(2,12) & 0.6473 \\
Obs*R-squared & 1.258869 & Prob. Chi-Square(2) & 0.5329 \\
\hline
\end{tabular}

Sumber : Lampiran 4

Uji autokorelasi menggunakan Breusch-Godfrey Serial Correlation LM Test menunjukkan Prob. ChiSquare $>\boldsymbol{\alpha}$, yaitu 0.5329 > 0.05, maka penelitian ini bebas autokorelasi (Gujarati 2012).

\section{Hasil dan pembahasan}

Uji t dilakukan untuk mengetahui pengaruh variabel independen secara parsial terhadap variabel dependen. Uji t dapat dilakukan dengan melihat nilai probability. Apabila nilai probability $<\alpha 5 \%$ maka koefisien variabel tersebut signifikan mempengaruhi variabel terikat dan sebaliknya (Gujarati 2012). Hasil dari uji t tersebut dapat dilihat dari hasil regresi pengolahan data berikut.

Tabel 5. Hasil Regresi Pengolahan Data

\begin{tabular}{lllll}
\hline Variable & Coefficient & Std. Error & t-Statistic & Prob. \\
\hline UMP & $2.69 \mathrm{E}-15$ & $7.19 \mathrm{E}-16$ & 3.745822 & 0.0022 \\
PDBLN & 0.460292 & 0.049197 & 9.356148 & 0.0000 \\
INFLASI & -0.003867 & 0.009891 & -0.390939 & 0.7017 \\
C & 9.895961 & 0.712413 & 13.89077 & 0.0000 \\
\hline
\end{tabular}

Variabel upah minimum menunjukkan nilai probability 0,0022 , lebih kecil dari $\alpha=0.05$, sehingga variabel upah minimum berpengaruh positif signifikan terhadap kepesertaan BPJS Ketenagakerjaan penerima upah. Ini berarti saat upah minimum mengalami kenaikan, jumlah peserta BPJS Ketenagakerjaan penerima upah juga mengalami kenaikan.

Hasil ini sesuai dengan penelitian oleh Rohmawati et al. (2014) di Surakarta, Ariska et al. (2016) di Kabupaten Jember, Puspitasari (2017) di Kabupaten Jamber dan Hasibuan (2017) di Provinsi DKI Jakarta menyatakan bahwa kenaikan dari upah/pendapatan berpengaruh positif secara signifikan terhadap keikutsertaan pekerja menjadi peserta jaminan sosial/asuransi jiwa.

Upah minimum di Indonesia ditetapkan oleh pemerintah provinsi masing-masing berdasarkan Kebutuhan Hidup Layak (KHL) dan mengalami perubahan setiap tahun dan selalu meningkat setiap tahun. Upah minimum yang banyak pihak dianggap membebani perusahaan dan dapat mengakibatkan terjadi Pemutusan Hubungan Kerja (PHK), dalam kasus di Indonesia, hasil perhitungan menunjukkan pengaruhnya positif dan signifikan. Hal ini terjadi karena Indonesia pasar tenaga kerja cenderung merupakan pasar monopsoni.Ju,lah pencari kerja jumlah sangat banyak semenrtara jumlah perusahaan 
yang membutuhkan tenaga kerja relative sedikit. Pada Grafik 1 di bawah, penetapan upah pada saat $\mathrm{ME}_{\mathrm{L}}=$ $\mathrm{MRP}_{\mathrm{L}}$, di titik A. Berdasarkan pertimbhangan tersebut, penetapan upah pada pasar monopsoni $\mathrm{W}_{0}$ dengan kesempatan kerja $\mathrm{E}_{0}$.. Pada saat pemerintah menetapkan upah minimum sebesar $W m$ (berada di atas $W_{0}$ ) yang terjadi bukan terjadi pemutusan hubungan kerja, tetapi jurtru kesempatabn kerja bertamnbah dari $E_{0}$ menjadi Em (Ehrenberg dan Smith 2012). Dengan tambahan kesempatan kerja, dapat dimengerti kaluaa peserta BPJS Ketenagakerjaan penerima upah juga meningkat.

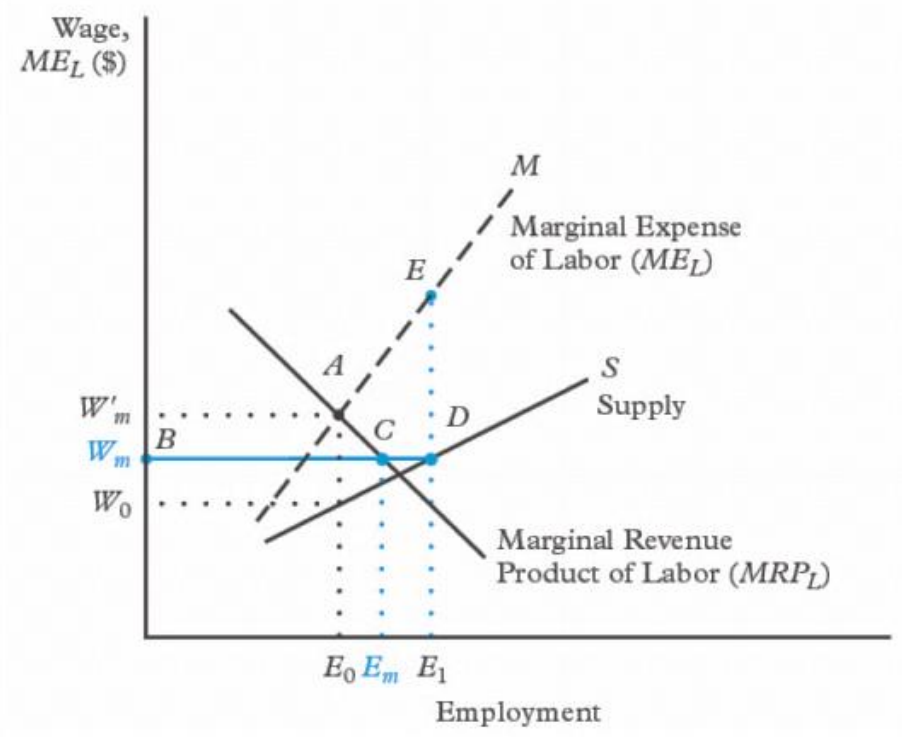

Grafik 1. Upah Minimum pada Pasar Monopsoni (Ehrenberg dan Smith 2012)

Variabel PDB sektor industri menunjukkan nilai probability 0,0000 , lebih kecil dari $\alpha(0,05$ atau $5 \%$ ), sehingga variabel PDB sektor industri berpengaruh positif signifikan terhadap kepesertaan BPJS Ketenagakerjaan penerima upah. Ini berarti saat PDB sektor industri mengalami kenaikan, jumlah peserta BPJS Ketenagakerjaan penerima upah juga akan mengalami kenaikan.

Melihat penelitian sebelumnya, tampak bahwa PDB negara juga akan berimbas pada keikutsertaan masyarakat pada asuransi jiwa. Hasil ini sesuai dengan penelitian dari Ward dan Zurbruegg (2002) di 37 negara yang tergabung dalam Organization for Economic Cooperation and Development (OECD) dan Asia periode 1987 - 1998, Kugler dan Ofoghi (2005) di Inggris selama periode 1966-2003, Adams et al., (2005) pada Swedia untuk periode 1830-1998, Arena (2006) di 56 negara industri dan berkembang, Njegomir dan Stojić (2010) di Yugoslavia untuk periode 2004-2008, Kjosevaki (2012) pada 14 negara Eropa Tengah dan tenggara tahun 1998-2010, Zouhaier (2014) pada 23 negara anggota OECD tahun 1990-2011, Burić et al. (2017) di 6 negara Balkan Barat periode 2005-2015 dan penelitian Prihantoro et al. (2013) di Indonesia.

Sumbangan PDB sektor industri pengolahan terhadap total PDB Indonesia dari tahun 2000-2017 mencapai angka sekitar 20\% dan kerap masuk dalam jajaran sektor penyumbang PDB tertinggi (BPS 2019). Hal ini tentu menjadi perhatian bagi pemerintah dalam mengembangkan dunia industri di Indonesia, apalagi sekarang Indonesia sedang fokus untuk program Making Indonesia 4.0. Diketahui bahwa jumlah pelaku usaha di Indonesia sangatlah besar dan selalu bertambah setiap tahunnya (BPS 2019). Peserta penerima upah BPJS Ketenagakerjaan didominasi para pekerja yang bekerja pada usaha skala besar (BPJS Ketenagakerjaan 2019). Berikut data jumlah pekerja usaha besar. 


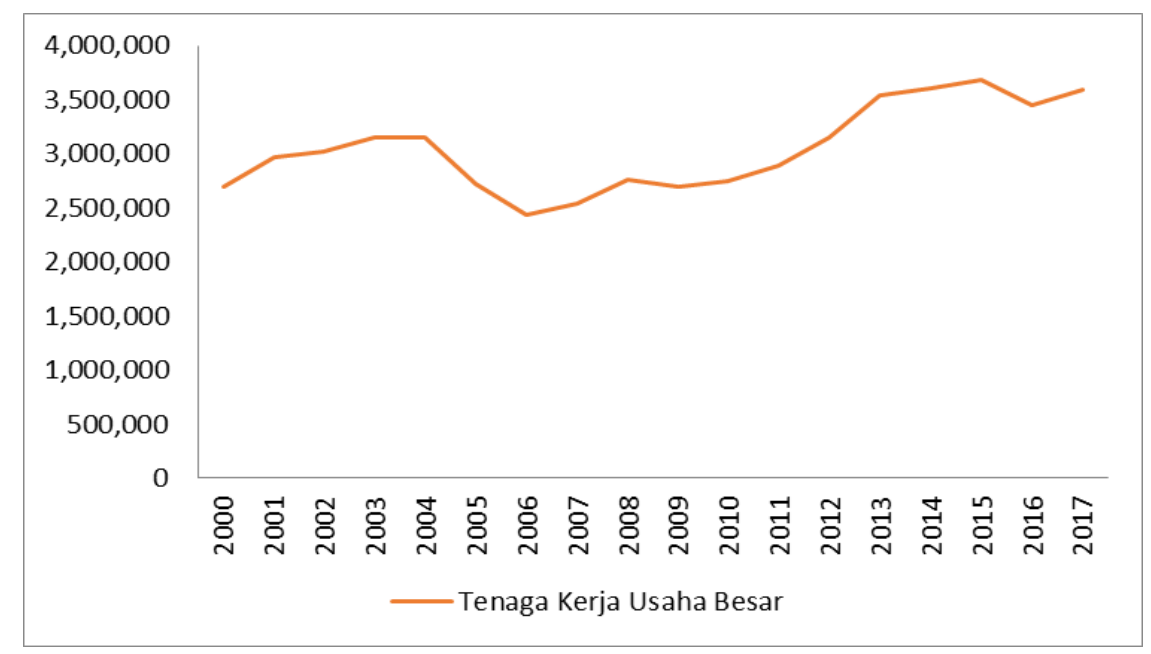

Sumber : BPS 2019, data diolah

Grafik 2. Jumlah Tenaga Kerja pada Usaha Besar 2000-2017 (jiwa)

Jumlah pekerja pada usaha besar cenderung mengalami kenaikan setiap tahun. Hal ini sejalan dengan jumlah kepesertaan BPJS Ketenagakerjaan penerima upah yang cenderung mengalami kenaikan setiap tahunnya.

Berdasarkan data BPJS Ketenagakerjaan (2019), jumlah perusahaan yang terdaftar menjadi peserta BPJS Ketenagakerjaan ditahun 2017 sebesar 488.118 perusahaan yang didominasi oleh perusahaan besar. Dengan kontribusi PDB sektor industri yang besar dan peningkatan tenaga kerja pada usaha besar serta sejalan dengan kenaikan jumlah peserta penerima upah BPJS Ketenagakerjaan, hal ini menunjukkan bahwa PDB sektor industri memang berpengaruh positif secara signifikan terhadap kepesertaan penerima upah BPJS Ketenagakerjaan tahun 2000-2017.

Variabel inflasi menunjukkan nilai probability 0,7017 dan lebih besar dari $\alpha(0,05$ atau 5\%), artinya variabel inflasi tidak berpengaruh terhadap kepesertaan BPJS Ketenagakerjaan penerima upah. Ini berarti perubahan angka inflasi pengaruhnya tidak signifikan terhadap kepesertaan BPJS Ketenagakerjaan penerima upah.

Hasil ini sesuai dengan penelitian Nesterova (2008) data historis 11 tahun terhadap 14 negara di Eropa Timur, Boubaker dan Sghaier (2012) dalam jangka pendek dan Kjosevaki (2012) pada 14 negara Eropa Tengah dan Tenggara tahun 1998-2010 yang menyatakan bahwa infalsi tidak berpengaruh terhadap kepesertaan jaminan sosial di tempat yang mereka teliti.

Inflasi Indonesia dari tahun 2000-2017 berfluktuasi setiap tahun atau dapat dikatakan tidak stabil. Dari tahun 2000-2017 diketahui bahwa inflasi tertinggi terjadi ditahun 2005 dengan tingkat inflasi sebesar $17,11 \%$ dan terendah terjadi ditahun 2009 dengan tingkat inflasi sebesar 2,78\%, serta inflasi mulai stabil diangka 3\% tahun 2015-2017 (BPS 2019).

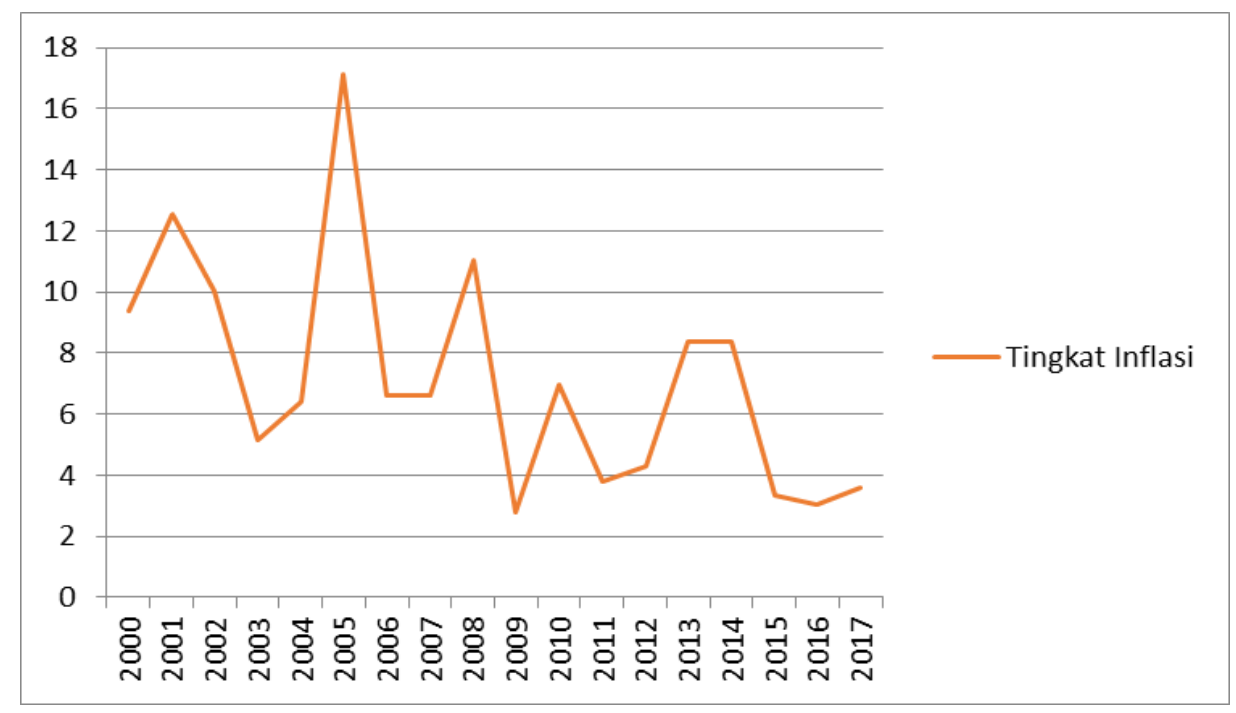

Sumber : BPS 2019, data diolah. 
Grafik 3Tingkat Inflasi Indonesia 2000-2017

Kondisi inflasi Indonesia tahun 2000-2017 tidak mempengaruhi kepesertaan BPJS Ketenagakerjaan penerima upah. Inflasi tinggi menyebabkan perusahaan terdorong untuk menyerap tenaga kerja karena tingginya harga-harga barang sehingga produksi akan meningkat. Sedangkan ketika inflasi rendah, perusahaan terdorong untuk melakukan PHK bagi pekerjanya karena harga-harga yang cenderung rendah sehingga produksi cenderung turun.

Kenyataannya, saat inflasi berfluktuasi, kepesertaan BPJS Ketenagakerjaan cenderung mengalami kenaikan setiap tahunnya. Bahkan saat inflasi mencapai angka 17,11\% ditahun 2005, hal tersebut malah menyebabkan penurunan jumlah peserta BPJS Ketenagakerjaan penerima upah sebesar 1,64\% dan saat ditahun 2009 dengan tingkat inflasi sebesar 2,78\% malah meningkatkan jumlah peserta BPJS Ketenagakerjaan penerima upah sebesar 2,48\%, sehingga fluktuasi dari inflasi tidak mempengaruhi kepesertaan BPJS Ketenagakerjaan penerima upah.

\section{Simpulan dan saran}

Upah minimum berpengaruh positif dan sitgnikan terhadap Kepesertaan BPJS Ketenagakerjaan penerima upah. Kesejahteraan merupakan hak setiap rakyat, terkhusus pekerja. Kesejahteraan tidak hanya diukur dari seberapa besar upah yang diterima, namun juga rasa aman saat bekerja. Pemerintah harus tegas pada pihak pemberi kerja akan kewajiban untuk menguikut sertakan karyawannya menjadi peserta BPJS Ketenagakerjaan

PDB sektor industri berpengaruh positif dan signifikan terhadap kepesertaan BPJS Ketenagakerjaan penerima upah. Meningkatnya PDB akan diikuti dengan meningkatnya jumlah tenaga kerja yang dipergunakan. PDB sektor industri lebih banyak didukung industri besar dan sedang. Bagi industri besar dan sedang wajib mengikut sertakan karyawannya pada program BPJS Ketenagakerjaan, Dapat dimengerti dengan semakin meningkat PDB sektor industri akan diikuti denagn semkin meningkatnya Kepesertaan BPJS Ketenagakerjaan.

\section{Daftar Rujukan}

Adams, Mike, Jonas Andersson, Lars-Fredrik Andersson, and Magnus Lindmark. 2005. The Historical Relation between Banking, Insurance, and Economic Growth in Sweden : 1830 to 1998. University of Wales Swansea Working Paper, UK.

Arena, Marco. 2006. Does Insurance Market Activity Promote Economic Growth? A Cross Country Study for Industrialized and Developing Countries. World Bank Policy Research Working Paper No. WPS4098.

Ariska, Nova, Eri Witcahyo, and Erdi Istiaji. 2016. Analisis Demand Masyarakat Pesisir Terhadap Kepesertaan Pada Jaminan Kesehatan Nasional Di Kecamatan Puger Kabupaten Jember Tahun 2016 (Demand Analysis of Membership in Coastal Community to the National Health Insurance at Puger Subdistrict Jember 2016). Artikel Ilmiah Hasil Penelitian Mahasiswa 2016 Universitas Jember.

Boubaker, Heni, and Nadia Sghaier. 2012. How Do the Interest Rate and the Inflation Rate Affect the NonLife Insurance Premiums? Bulletin Français D'Actuariat 12 (24): 87-111. http://www.ressourcesactuarielles.net/EXT/IA/sitebfa.nsf/0/C99AEA67ECBF21ECC1257AA3006E93DD/\$FILE/24_Articl e4.pdf?OpenElement.

Badan Pusat Statistik. 2019a. Inflasi Indonesia. Retrieved January 11, 2019, from https://www.bps.go.id

Badan Pusat Statistik. 2019b. Penduduk Usia 15 Tahun Keatas Menurut Status Pekerjaan Utama. Retrieved January 11, 2019, from https://www.bps.go.id

Badan Pusat Statistik. 2019c. Produk Domestik Bruto Atas Dasar Harga Konstan. Retrieved January 11, 2019, from https://www.bps.go.id.

Badan Pusat Statistik. 2019d. Upah Minimum Indonesia. Retrieved January 11, 2019, from https://www.bps.go.id 
BPJS Ketenagakerjaan. 2006. Laporan Tahunan BPJS Ketenagakerjaan. BPJS Ketenagakerjaan. 2007. Laporan Tahunan BPJS Ketenagakerjaan. BPJS Ketenagakerjaan. 2008. Laporan Tahunan BPJS Ketenagakerjaan. BPJS Ketenagakerjaan. 2009. Laporan Tahunan BPJS Ketenagakerjaan. BPJS Ketenagakerjaan. 2010. Laporan Tahunan BPJS Ketenagakerjaan. BPJS Ketenagakerjaan. 2011. Laporan Tahunan BPJS Ketenagakerjaan. BPJS Ketenagakerjaan. 2012. Laporan Tahunan BPJS Ketenagakerjaan. BPJS Ketenagakerjaan. 2013. Laporan Tahunan BPJS Ketenagakerjaan. BPJS Ketenagakerjaan. 2014. Laporan Tahunan BPJS Ketenagakerjaan. BPJS Ketenagakerjaan. 2015. Laporan Tahunan BPJS Ketenagakerjaan. BPJS Ketenagakerjaan. 2016. Laporan Tahunan BPJS Ketenagakerjaan. BPJS Ketenagakerjaan. 2017. Laporan Tahunan BPJS Ketenagakerjaan.

BPJS Ketenagakerjaan. 2019. Peserta Penerima Upah dan Bukan Penerima Upah. Retrieved from https://www.bpjsketenagakerjaan.go.id

Burić, Milijana Novović, Julija Cerović Smolović, Milena Lipovina Božović, and Ana Lalević Filipović. 2017. Impact of Economic Factors on Life Insurance Development in Western Balkan Countries. Zbornik Radova Ekonomskog Fakulteta u Rijeci: Časopis Za Ekonomsku Teoriju i Praksu / Proceedings of Rijeka Faculty of Economics: Journal of Economics and Business 35 (2): 331-52. https://doi.org/10.18045/zbefri.2017.2.331.

Ehrenberg, R. G., and R. S. Smith. 2012. Modern Labor Economics: Theory Public Policy. Pearson Education, Inc. New York City.

Gujarati, Damodar N. 2012. Dasar-Dasar Ekonometrika. Jakarta: Salemba Empat, Buku 2, Edisi 5 terjemahan Mangunsong, R.C.

Gultom, Ratih Yasnuarni. 2016. Pengaruh Perkembangan Makro Ekonomi Indonesia terhadap Pertumbuhan Kepesertaan BPJS Ketenagakerjaan. Jurnal Institut BPJS Ketenagakerjaan Tahun 2016 Volume 1.

Hasibuan, Zharifah Putri Masturah. 2017. Analisis Faktor Sosial Ekonomi Tenaga Kerja Yang Memengaruhi Perusahaan Menyediakan Jaminan Kesehatan Di Provinsi DKI Jakarta. Jurnal Institut Pertanian Bogor.

Kjosevski, Jordan. 2012. The Determinants of Life Insurance Demand in Central and Southeastern Europe. International Journal of Economics and Finance 4 (3): 237-47. https://doi.org/10.5539/ijef.v4n3p237.

Kugler, Maurice, and Reza Ofoghi. 2010. Does Insurance Promote Economic Growth: The Evidence from Ex-Yugoslavia Region. Ekonomska Misao i Praksa 1 (January 2016): 31-48. http://hrcak.srce.hr/index.php?show=clanak\&id_clanak_jezik=83216.

Nesterova, Daria. 2008. Determinants of The Demand for Life Insurance: Evidence From Selected CIS and CEE Countries. National University Kyiv-Mohyl Academy 14-15. 
Njegomir, Vladimir, and Dragan Stojic. 2010. Determinants of Insurance Market Attractiveness For Foreing Investments : The Case Of Ex-Yugoslavia. Ekonomska Istraživanja, Vol. 23 (2010) No. 3(96110) Monopolies 22: 96-110.

Pangestika, Viona Febya, Sutopo Patria Jati, and Ayun Sriatmi. 2017. Faktor-Faktor Yang Berhubungan Dengan Kepesertaan Sektor Informal Dalam BPJS Kesehatan Mandiri Di Kelurahan Poncol, Kecamatan Pekalongan Timur, Kota Pekalongan. Jurnal Kesehatan Masyarakat (E-Journal) Volume 5, Nomor 3, Juli $2017 \quad$ ISSN: $2356-3346 \quad$ 5: https://media.neliti.com/media/publications/163373-ID-faktor-faktor-yang-berhubungandengan-ke.pdf.

Prasetyo, Budi. 2016. Faktor-Faktor yang Berhubungan dengan Kepesertaan Badan Penyelenggara Jaminan Sosial Kesehatan Mandiri pada Masyarakat Kelurahan Tanjung Puri Tahun 2015. Jurnal Wawasan Kesehatan - ISSN 2087 - 4995 Volume 3 81-89, Nomor 1.

Prihantoro, Imam Basuki, and Kasir Iskandar. 2013. Analisis Faktor-Faktor Makro Ekonomi dan Demografi terhadap Fungsi Permintaan Asuransi Jiwa di Indonesia. Jurnal Asuransi dan Manajemen Risiko 1 No: 1: 16-41.

Puspitasari, Yuli. 2017. Faktor yang Mempengaruhi Partisipasi Kepesertaan Jaminan Kesehatan Nasional Pada Pekerja Bukan Penerima Upah Di Desa Kasiyan Timur Wilayah Kerja Puskesmas Kasiyan Kabupaten Jember Tahun 2016. Digital Respiratory Universitas Jember. http://repository.unej.ac.id/handle/123456789/80978.

Republik Indonesia. 1995. Peraturan Pemerintah Nomor 36 Tahun 1995 tentang Penetapan Badan Penyelenggara Program Jaminan Sosial Tenaga Kerja.

Republik Indonesia. 2011. Undang-Undang Republik Indonesia Nomor 24 Tahun 2011 Tentang Badan Penyelenggara Jaminan Sosial (c.1).

Rohmawati, Desy. 2014. Hubungan Pengetahuan Sikap dan Sosial Ekonomi dengan Pemilihan Jenis Iuran Keikutsertaan JKN Mandiri pada Wilayah Cakupan JKN Tertinggi di Surakarta. Artikel Penelitian Universitas Muhammadiya Surakarta.

Ward, Damian, and Ralf Zurbruegg. 2002. Law, Politics and Life Insurance Consumption in Asia.: UEA Library Search - Books, Articles and More. The Geneva Papers on Risk and Insurance 27 (3): 395412. $\quad$ http://eds.b.ebscohost.com/eds/pdfviewer/pdfviewer?sid=bf920622-4a83-46fb-84b9b0977828ee58\%40sessionmgr103\&vid=0\&hid=121.

Zouhaier, Hadhek. 2014. Insurance and Economic Growth. Journal of Public Economics 38 (2): $249-64$. https://doi.org/10.1016/0047-2727(89)90028-5. 